\title{
Suitability of On-Farm Green Compost for the Production of Baby Leaf Species
}

\author{
Enrica De Falco, Antonella Vitti * (D), Giuseppe Celano and Domenico Ronga $\mathbb{D}$ \\ Pharmacy Department, University of Salerno, Via Giovanni Paolo II n. 132, 84084 Fisciano, SA, Italy; \\ edefalco@unisa.it (E.D.F.); gcelano@unisa.it (G.C.); dronga@unisa.it (D.R.) \\ * Correspondence: avitti@unisa.it
}

check for updates

Citation: De Falco, E.; Vitti, A.; Celano, G.; Ronga, D. Suitability of On-Farm Green Compost for the Production of Baby Leaf Species. Horticulturae 2021, 7, 512. https:// doi.org/10.3390/horticulturae7110512

Academic Editors: Stefania De Pascale and Pietro Santamaria

Received: 24 September 2021 Accepted: 18 November 2021 Published: 20 November 2021

Publisher's Note: MDPI stays neutral with regard to jurisdictional claims in published maps and institutional affiliations.

Copyright: (c) 2021 by the authors. Licensee MDPI, Basel, Switzerland. This article is an open access article distributed under the terms and conditions of the Creative Commons Attribution (CC BY) license (https:// creativecommons.org/licenses/by/ $4.0 /)$.
Abstract: This study evaluated, for the first time, the suitability of on-farm green compost (GC) from the fourth range sector for the production, in a controlled environment, of six baby leaf species (radish, lettuce, rocket, chard, sorrel and dill), characterized by short cultivation cycles. The $\mathrm{pH}$ and electrical conductivity of potting soil-compost mixtures were affected by the different amounts of GC added to the potting soil. Germination tests on Lactuca sativa seeds indicated no phytotoxic effects when GC was used to prepare aqueous extracts diluted at $50 \%$ and $25 \%(v / v)$. In the pot experiment, GC was used at four different dosages in the growing medium, inducing different impacts on growth parameters, depending on the species and applied dose. The greatest plant growth responses were determined by using less than $3.5 \mathrm{~g}$ of GC in $100 \mathrm{~g}$ of potting soil. Significant positive correlations between the dry weights of root and shoot $\left(\mathrm{r}=0.77^{* *}\right)$, seedling height $\left(\mathrm{r}=0.51^{* *}\right)$ and the number of true leaves number $\left(\mathrm{r}=0.56^{* *}\right)$ confirmed the close relationship between the root system biomass and the growth parameters of aboveground organs. The study highlights that on-farm green compost, used as partial growing substrate, provides a good opportunity to obtain baby leaf species with well-developed root systems.

Keywords: organic amendment; pot substrate; sustainable production; species for salads; controlled environment

\section{Introduction}

The adequate management of agroindustrial by-products represents a crucial issue for increasing the sustainability of agricultural systems. The use of microbiologically stabilized organic amendments, such as composted materials, is certainly one of the most sustainable tools for enhancing organic matter and nutrients in soil and growth substrates [1].

Composting represents a degradation process of fresh organic matter by microorganisms, which involves biochemical and exothermic transformations. Through this process, stable and humified organic matter is obtained from agricultural biomass wastes; it can be used as a sustainable organic fertilizer to replace chemical fertilizers [2-4].

Compost is employed in many ways as a substitute for materials such as peat and potting soil in nurseries, gardening and other contexts; its positive effects have been demonstrated, including the ability to act as a biostimulant of plant growth and development, even under intensive farming systems [5-8].

Compost is successfully used in horticultural media during the first stages of plant emergence and development and is also successfully mixed with substrates for vegetable transplants. One study assessed that compost is able to increase the seed germination and seedling growth of chilli (Capsicum annuum L. cv. BARI Marich 1) [9]. Compost has been positively evaluated as a substitute for peat in the production of tomato (Solanum lycopersicum L. cv. Marlglobe) seedlings in nurseries [10] and for the production of tomato (cv. Roma V.F.) and basil (Ocimum basilicum L. cv. Italiano Classico) potting plants [11]. In addition, some authors have reported that compost mixed with peat is a suitable substrate for the growth of horticultural species cropped in the greenhouse such as tomato (cv. 
Malpica), zucchini (Cucurbita pepo L. cv. Mastil F1) and pepper (Capsicum annuum L. cv. Largo de Reus Pairal), three vegetable species with low, moderate and high sensitivity to salinity, respectively [12], while another study indicated that compost was a good transplant substrate for basil (cv. Dark Opal), chives (Allium schoenoprasum) and dill (Anethum graveolens cv. Hera') [13].

Regarding sustainability, the on-farm composting approach has been well established as a tool to recycle agricultural waste from the perspective of the transition from a linear production system to a circular economy (Reduce, Reuse, Recycle) in which the residues at the end of a production process are re-evaluated as resources [14]. A concrete and interesting possibility is the creation of connections between agricultural farms producing soil amendments from crop residues and other productive farms, such as nurseries, that use those soil amendments in the next step [15]. In this regard, a partial substitution of peat in potting mixes with on-farm compost produced from green residues was carried out in the production of olive pot plants [16].

However, based on the authors' knowledge, no study has investigated the suitability of using on-farm compost derived from the fourth range sector (ready-to-eat products) as part of a growing medium for the production of baby leaf species, which are characterized by short cultivation cycles, intended for the same fourth range sector, despite these packaged, fresh-cut and raw vegetables becoming more and more popular in the modern consumer lifestyle because they are considered healthy, as well as quick and easy to prepare [17].

Accordingly, the aim of this study was to evaluate the possibility of using on-farm green compost, obtained from fourth range cultivation waste, as a substrate for the production, in a controlled environment, of different horticultural species used in salad preparation, through the evaluation of its effects on the main growth parameters.

\section{Materials and Methods}

\subsection{Compost and Growing Media}

The on-farm green compost was provided by the farm "TERRAMORE Soc. Coop." (Eboli, SA, Italy). It was derived from the recovery cultivation residues of this farm, based on green leafy vegetables destined for fourth range industry.

Green compost was analyzed by an external laboratory (Cierre S.r.l., Arezzo, Italy), before the trial began, in order to verify its suitability for agricultural use on the basis of the current Italian Legislative Decree 75/2010 and recent EU Regulation 2019/1009. The analysis showed that all parameters were below the legal limits and were specific to a quality compost (Table 1). In particular, the low concentration of heavy metals ensured that they did not represent an abiotic stress-inducing factor; moreover, the very low number of E. coli and the absence of Salmonella spp. confirmed a good degree of maturation. The C/N ratio of 10.3 indicated that the composting process had developed appropriately.

The commercial potting soil Triplo Energy \& Life (TerComposti S.P.A., Calvisano, BS, Italy) was used for preparing the plant growth media in combination with the on-farm green compost.

The substrates were prepared by adding $7.0 \mathrm{~g}$ of green compost per $100 \mathrm{~g}$ of potting soil (C100) and then mixing $5.25 \mathrm{~g}, 3.5 \mathrm{~g}$ and $1.75 \mathrm{~g}$ per $100 \mathrm{~g}$ of potting soil (C75, C50, C25), equal to $75 \%, 50 \%$ and $25 \%$ of the maximum dose of green compost.

Samples of compost, potting soil and their combinations were taken to determine $\mathrm{pH}$ and electrical conductivity (EC) (PC 5 tester, XS Instruments, Carpi, MO, Italy) using suspensions soil/deionized water $(1: 5 w / v)$. The measurements were repeated three times. 
Table 1. Properties of green compost used in the experiment, released by the external laboratory (Cierre S.r.l., Arezzo, Italy).

\begin{tabular}{|c|c|}
\hline Parameter & Compost \\
\hline Cadmium (mg kg ${ }^{-1}$ d.m.) & 0.426 \\
\hline Chrome VI (as Cr) (mg kg ${ }^{-1}$ d.m.) & $<0.1$ \\
\hline Mercury (mg kg ${ }^{-1}$ d.m.) & $<0.5$ \\
\hline Nickel (mg kg ${ }^{-1}$ d.m.) & 3.78 \\
\hline Lead (mg kg ${ }^{-1}$ d.m.) & 9.23 \\
\hline Copper (mg kg ${ }^{-1}$ d.m.) & 115 \\
\hline Zinc (like $\mathrm{Zn})\left(\mathrm{mg} \mathrm{kg}^{-1}\right.$ d.m.) & 75.6 \\
\hline Thallium ( $\left.\mathrm{mg} \mathrm{kg}^{-1} \mathrm{~d} . \mathrm{m}.\right)$ & $<0.5$ \\
\hline Enumeration of Escherichia coli (n. 1) (MPN g $\left.{ }^{-1}\right)$ & 67 \\
\hline Enumeration of Escherichia coli (n. 2) (MPN g $\left.{ }^{-1}\right)$ & 67 \\
\hline Enumeration of Escherichia coli (n. 3) (MPN g $\left.{ }^{-1}\right)$ & 44 \\
\hline Enumeration of Escherichia coli (n. 4) (MPN g $\left.{ }^{-1}\right)$ & $<11$ \\
\hline Enumeration of Escherichia coli (n. 5) (MPN g $\left.{ }^{-1}\right)$ & $<11$ \\
\hline Salmonella spp. $(\mathrm{n}=5)$ (Present or Absent) & Absent \\
\hline Moisture $\left(105^{\circ} \mathrm{C}\right)(\%)$ & 4.8 \\
\hline Total organic carbon (TOC) of biological origin (\% d.m.) & 20.1 \\
\hline Humic and fulvic acids HA + FA (as humic C) (\% d.m.) & 7.8 \\
\hline Total nitrogen (as N) (\% d.m.) & 1.96 \\
\hline $\mathrm{C} / \mathrm{N}$ ratio & 10.3 \\
\hline Organic nitrogen (as \% of total N) (\% NTK) & 90.9 \\
\hline Total phosphorus (as P) (\% d.m.) & 0.56 \\
\hline Total potassium (as K) (\% d.m.) & 1.34 \\
\hline Plastic, glass and metals ( $\geq 2 \mathrm{~mm})$ & $<0.01$ \\
\hline Lithoids inerts $(\geq 5 \mathrm{~mm})$ & $<0.01$ \\
\hline
\end{tabular}

d.m. = dry matter; MPN = most probable number.

\subsection{Biological Assay}

Air-dried green compost was used to prepare aqueous extracts for the germination assay. One hundred grams of the green compost was suspended in $1000 \mathrm{~mL}$ of distilled water to reach an extraction ratio of 1:10 (w/v). After agitation at 200-250 rpm for $45 \mathrm{~min}$, sedimentation for $24 \mathrm{~h}$ and sterile membrane filtration, the supernatant was recovered and stored at $4{ }^{\circ} \mathrm{C}$ until use.

For the germination assay, the undiluted aqueous extracts $(100 \%)$, as well as three dilutions at $75 \%, 50 \%$ and $25 \%$ in sterile, distilled water, were prepared. Ten milliliters of each aqueous extract and 10 seeds of Lactuca sativa L. (cv. Batavia verde Falstaff) were placed on filter paper in a Petri dish and kept in the dark $\left(48 \mathrm{~h}\right.$ at $\left.20-25^{\circ} \mathrm{C}\right)$. Sterile, distilled water was used as a control and three replicates were set out for each treatment. The number of normally germinated seeds was counted, and the primary radicle lengths (root + hypocotyl) were measured.

The germination index (GI) was calculated according to the following formula (1), considering phytotoxicity to be absent when the value was equal or higher than $80 \%$ [18]:

GI $(\%)=[($ Number of germinated seeds in the sample/Number of germinated seeds in the control) $\times$ (Total radicle length of germinated seeds in the sample/Total radicle length of germinated seeds in the control)] $\times 100$,

\subsection{Pot Experiment}

The experiment was performed in the spring period of 2019 at the Campus of the University of Salerno (Fisciano, SA, Italy) in a glass greenhouse. During the entire experimentation, the temperature ranged from 21 to $26^{\circ} \mathrm{C}$, air humidity ranged from $60 \%$ to $70 \%$ and the photoperiod was $16 / 8 \mathrm{~h}$, light/dark. 
The growing media used to fill the pots consisted solely of commercial potting soil (T), used as the control, and the four treatment mixtures, each with a different proportion of compost (C100, C75, C50 and C25), as described above.

Six different species were separately sown in $10 \mathrm{~cm}$ diameter pots (five seeds per pot) with three replications for each treatment, according to a completely randomized design. The six species were: radish (Raphanus satious L.) var. Tondo rosso; lettuce, var. Batavia verde Falstaff; wild rocket (Diplotaxis tenuifolia L.) var. Marte; chard (Beta vulgaris L.) var. Bull's Blood Morello with dark red leaves; sorrel (Rumex acetosa L.) var. Red Sorrel; dill (Anethum graveolens L.) var. Dukat.

Pots were manually irrigated with tap water every day up to field water capacity. The end of the experimentation for each species was considered to be when the seedlings developed a number of leaves and reached a height considered proper for harvesting (on average, 21 days after sowing for radish and lettuce and 42 days for the other species). The emergence was monitored daily. Plant heights, measured from ground level to the tip of the apical shoot for each seedling, were recorded weekly until the end of the trial.

Similarly, the number of total leaves per plant (excluding cotyledons) for each seedling were counted and the SPAD index (SPAD-502 Chlorophyll meter, Konica Minolta Sensing Europe B.V., Cinisello Balsamo, MI, Italy) was measured on the fully expanded leaves at the top of the plants with 3 measurements per plant. Because of the morphology of the leaves, SPAD determinations were not performed for dill.

Seedlings were carefully removed from the pots, soaked in water to remove rootattached growing medium particles, dried with paper towels to remove excess water and separated into shoot and root portions. The length of the main root of each seedling was measured; the fresh and dry weights (oven-dried at $65^{\circ} \mathrm{C}$ for $72 \mathrm{~h}$ ) of the shoots and roots were recorded.

\subsection{Statistical Analyses}

All data were Shapiro-Wilk and Bartlett's tested for normality and common variance of experimental error and log-transformed (ln) when required (untransformed data are reported in the results section). Significant differences among treatments were determined by factorial ANOVA, according to a completely randomized design with three replicates. Comparison among means was determined using the Tukey post-hoc test $(p=0.05)$ due to the equality of variances.

The data from the biological assay and pot experiment were expressed as percentages relative to the control (\%). All data were indicated as mean \pm standard error. Pearson's correlation analysis was performed at ${ }^{* *} p=0.01$ using the parameters of the greenhouse trial.

MSTAT-C software package (Michigan State University, East Lansing, MI, USA) was used.

\section{Results and Discussion}

\subsection{Compost and Growth Media Characteristics}

The $\mathrm{pH}$ and EC of compost, potting soil and the four growing media used in the experiments are reported in Table 2.

Green compost (GC) showed the highest significant values of $\mathrm{pH}$ and EC, while the lowest significant values were registered for the potting soil suspension $(T)$.

Through the addition of compost to the potting soil, the $\mathrm{pH}$ increased, reaching significantly higher values than T, except for the suspension at the lowest proportion (C25), which showed a $\mathrm{pH}$ increase of 0.07 , not significantly different from $\mathrm{T}$.

Analogous EC values increased with the doses of compost added to the substrate from C25 to C100 and were always significantly higher than that of the potting soil alone (T).

In the current study, the amounts of green compost added to the potting soil showed a reduced EC with respect to the green compost alone and, in any case, always maintained $\mathrm{pH}$ values between 6.36 and 6.14. In relation to this, another study reported slight acid/neutral $\mathrm{pH}$ values, between 5.2 and 7.0, and EC values between 200 and $1500 \mu \mathrm{Sm}^{-1}$ as optimal conditions for some greenhouse grown species [19]. We found that the $\mathrm{pH}$ of all substrates 
here considered was always in the range reported above; EC values of compost-enriched substrates were between 1843.68 and $1523.33 \mu \mathrm{S} \mathrm{cm}{ }^{-1}$, indicating $\mathrm{C} 25$ as a dose very close to this optimal condition. Moreover, it was demonstrated that the optimal EC values for Raphanus sativus and Beta vulgaris were equal to $2000-4000$ and $6700 \mu \mathrm{S} \mathrm{cm}^{-1}$, respectively $[20,21]$, suggesting the ability of these two species to grow well even in higher EC conditions. These parameters must be taken into account when defining the dose to be applied in relation to species in order to avoid an excessive increase in substrate salinity and a possible consequent inhibition, delay or reduction of plant growth.

Table 2. $\mathrm{pH}$ and electrical conductivity (EC) measurements for sample/distilled water suspension $(1: 5, w / v)$ of: green compost (GC); potting soil (T); mixtures containing the four different proportions of compost (C100, C75, C50, C25).

\begin{tabular}{ccc}
\hline Suspension & $\mathbf{p H}$ & $\mathbf{E C}\left(\boldsymbol{\mu S} \mathbf{~ c m}^{-\mathbf{1}}\right)$ \\
\hline GC & $8.40 \pm 0.05 \mathrm{a}$ & $4363.33 \pm 25.17 \mathrm{a}$ \\
T & $6.07 \pm 0.01 \mathrm{~d}$ & $1049.67 \pm 1.53 \mathrm{f}$ \\
C100 & $6.36 \pm 0.02 \mathrm{~b}$ & $1843.68 \pm 3.21 \mathrm{~b}$ \\
C75 & $6.20 \pm 0.03 \mathrm{c}$ & $1798.32 \pm 10.02 \mathrm{c}$ \\
C50 & $6.17 \pm 0.03 \mathrm{c}$ & $1685.67 \pm 3.21 \mathrm{~d}$ \\
C25 & $6.14 \pm 0.03 \mathrm{~cd}$ & $1523.33 \pm 15.01 \mathrm{e}$ \\
\hline
\end{tabular}

Data are reported as mean values $(n=3) \pm$ SD. Different letters within the same column indicate significant differences among the substrates, according to factorial ANOVA combined with Tukey post-hoc test at $p=0.05$.

\subsection{Biological Assay}

The results of the germination test carried out on lettuce, a plant recommended for toxicity tests [22] and compost quality assessment [23], are shown in Figure 1.

Seed germination was affected by the different aqueous extracts, with a significantly low number of germinated seeds observed in the aqueous extract with the highest concentration $(\mathrm{C} 100 \%)$ (Figure 1a,b). Root elongation was significantly and positively affected by compost addition at the lowest concentration (C25\%).

Overall, aqueous extracts induced phytotoxic effects (germination index, GI $<80 \%$ ) only on the seeds at the two highest concentrations (C100\% and $\mathrm{C} 75 \%)$, while at the lowest concentration (C25\%), the GI was higher than $100 \%$. These results confirm the previous $\mathrm{pH}$ and EC results; the phytotoxicity test highlighted the need to carefully define the dose of compost to apply in the growing media, to avoid phytotoxicity or an excess of salts or nutrients, in order to make its use eligible for the germination and cultivation of horticultural species [19].

\subsection{Greenhouse Pot Experiment}

The results of the growth parameters, measured for the six species in relation to the different compared substrates, are reported in Table 3.

Concerning the emerged seedlings, the values generally increased with the reduction of the percentage of compost added to the potting soil. The seedling germination was significantly higher for sorrel and dill at the lowest doses (C50 and C25), but with values always equal or higher than the control $(\mathrm{T})$ at all doses. By contrast, the values of the emerged seedlings for the other species were always equal or lower than the control. No significant difference was recorded for the rocket. The general significant reduction in the seed germination induced by the highest dose of the compost could probably be attributed to an inhibition of water uptake necessary for germination, linked, as mentioned above, to the higher salinity of the compost at that dose, as assessed for lettuce plants [24].

At the end of survey, the number of true leaves was generally lower than the control for all species, with exception of radish and chard. These two species showed significant, increasing and higher values than the control from C75 to C 25 doses. Again, rocket results were not influenced by the different doses. 

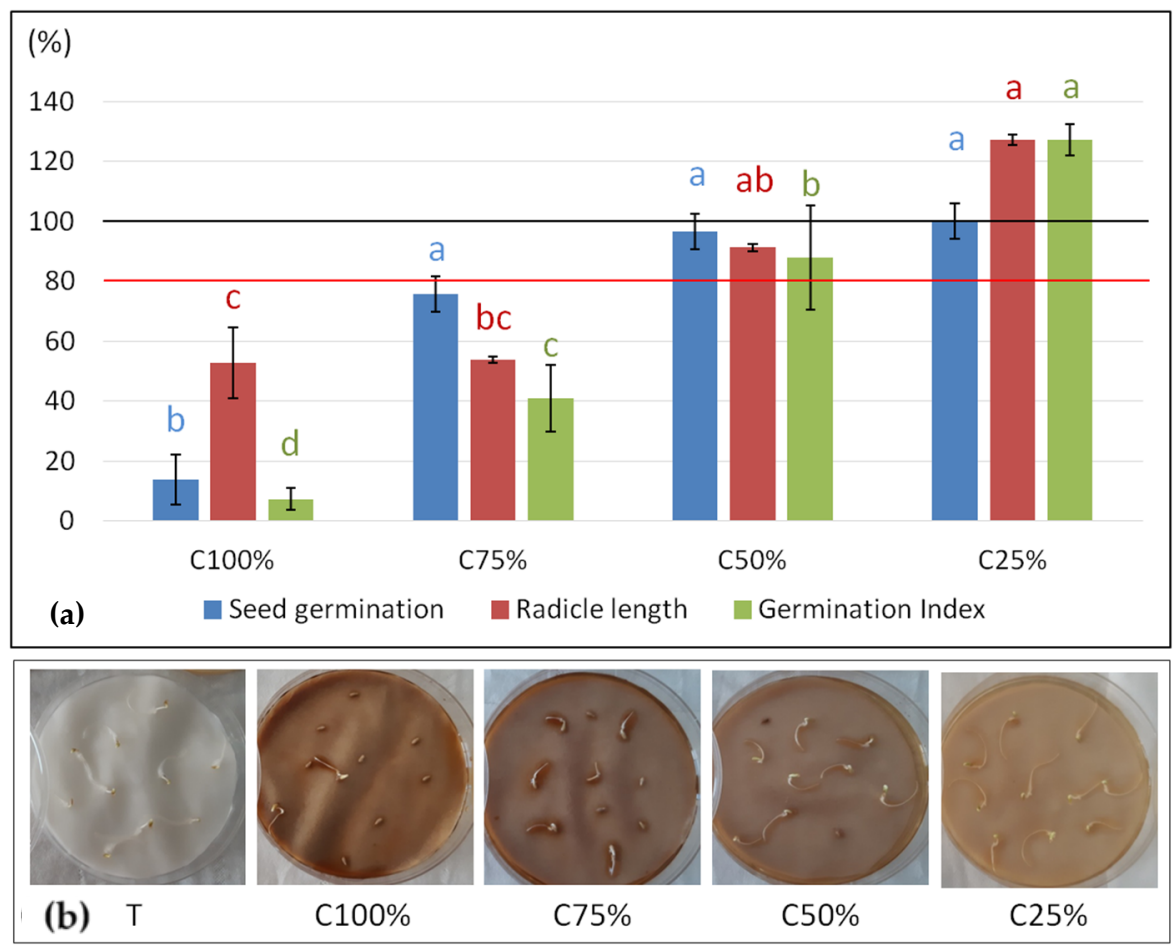

Figure 1. Phytotoxicity test, performed on Lactuca sativa L. seeds, using aqueous extracts from compost (C) undiluted (100\%) and diluted (75\%,50\% and 25\%). (a) Mean values of seed germination, root elongation and germination index are expressed as percentages relative to the control $(n=3)$. Bars represent SD of the mean. Different letters indicate significant differences $(p=0.05)$ among aqueous extracts, according to factorial ANOVA combined with Tukey post-hoc test. The black and red lines designate the percentages of the control and the phytotoxicity threshold, respectively. (b) Representative pictures of Petri dishes with seeds germinated in distilled water as control (T) and in all aqueous extracts after $48 \mathrm{~h}$ of dark incubation.

The addition of compost determined a general significant increase in the seedlings' height values, with the decrease in the percentage added, as observed in another study in which compost and vermicompost were used as peat substitutes in growing media for geranium (Pelargonium zonale L.) and calendula (Calendula officinalis L.) [25]. An exception was represented by the rocket, which showed values that were not significantly different among the doses of applications. Significant values well above $100 \%$ of the control were registered at low dosage for radish, chard and sorrel.

Concerning the parameter of shoot dry weight, the highest values were observed for the lowest dose (C25) with a very high significant increase when compared with the control in radish and chard. Rocket showed very low percentages without significant differences among the doses.

Furthermore, the root dry weights significantly increased with the reduction of the dose added to the substrate; they always reached higher values than control at the lowest dose (C25), with the exception of dill. Very high weight increases, with percentages of $106 \%, 102 \%, 63 \%$ and $42 \%$ above the control, were registered in chard, radish, lettuce and sorrel, respectively. It has been shown that compost is able to increase the availability of nutrients for the plant and promote the growth of the roots and the absorption of nutrients by the plant with an increase in dry weight of both shoots and roots [26,27]. Our findings confirmed such effects for radish, and also for chard, lettuce and sorrel, only when the lowest dosage was used. These results suggested that the capacity of root to absorb nutrient and root-to-shoot translocation strongly depends on the amendment dose added to the growth media and, at the same dose, also on the species. The results are in agreement with 
the conclusion of a study which reported that the effects of compost on plant growth in field nursery production were species-specific [28].

The elongation of the main root also differed depending on species (Table 3): it was generally lower than $100 \%$ of the control for lettuce, sorrel and dill and higher for radish, rocket and chard. Remarkably, rocket showed the highest significant value at the highest dose (C100). These finding can be explained because D. tenuifolia has been classified as a salt-tolerant species [29]. On the other hand, the nitrogen use efficiency of this species was probably quite low, so that it may require a different dose of compost than used in the current study or a longer time span between sowing and harvest in order to have more benefits for the other growth parameters [30]. In addition, compost is known to be a material rich in humic compounds [31], which probably need a longer time-period than that of the cultivation period used in this study to be explored and to become available for the considered species [32]. Effectively, the GC used in this study showed a good level of humic compounds, equal to $7.8 \%$ dry matter (Table 1 ); this might explain the fact that the results of the growth parameters for all considered species were not unequivocally positive.

Table 3. Growth parameters measured for each species at the end of survey with respect to the control (\%) at the different doses of compost added to the growth media.

\begin{tabular}{|c|c|c|c|c|c|c|c|}
\hline Species & $\begin{array}{l}\text { Growing } \\
\text { Medium }\end{array}$ & $\begin{array}{c}\text { Emerged } \\
\text { Seedlings } \\
\%\end{array}$ & $\begin{array}{c}\text { Leaves } \\
\text { Number } \\
\%\end{array}$ & $\begin{array}{c}\text { Seedlings } \\
\text { Height } \\
\%\end{array}$ & $\begin{array}{c}\text { Shoot Dry } \\
\text { Weight } \\
\%\end{array}$ & $\begin{array}{c}\text { Root Dry } \\
\text { Weight } \\
\%\end{array}$ & $\begin{array}{c}\text { Main Root } \\
\text { LENGTH } \\
\%\end{array}$ \\
\hline \multirow{4}{*}{ Radish } & C100 & $84.6 \pm 1.2 c$ & $101.1 \pm 1.1 \mathrm{c}$ & $86.1 \pm 1.1 \mathrm{~d}$ & $74.9 \pm 1.3 c$ & $105.7 \pm 1.8 \mathrm{c}$ & $107.0 \pm 1.0 \mathrm{~b}$ \\
\hline & $\mathrm{C} 75$ & $92.3 \pm 1.0 \mathrm{~b}$ & $119.3 \pm 1.1 b$ & $104.9 \pm 1.1 \mathrm{c}$ & $112.0 \pm 1.2 \mathrm{~b}$ & $110.6 \pm 1.1 c$ & $134.0 \pm 1.5 \mathrm{a}$ \\
\hline & C50 & $92.3 \pm 1.3 \mathrm{~b}$ & $122.3 \pm 1.0 \mathrm{~b}$ & $108.6 \pm 1.2 \mathrm{~b}$ & $117.0 \pm 1.1 \mathrm{~b}$ & $115.5 \pm 1.8 \mathrm{~b}$ & $138.8 \pm 1.2 \mathrm{a}$ \\
\hline & $\mathrm{C} 25$ & $100.0 \pm 1.3 \mathrm{a}$ & $136.3 \pm 1.0 \mathrm{a}$ & $122.9 \pm 1.2 \mathrm{a}$ & $187.7 \pm 1.2 \mathrm{a}$ & $201.9 \pm 1.5 \mathrm{a}$ & $136.5 \pm 1.0 \mathrm{a}$ \\
\hline \multirow{4}{*}{ Lettuce } & C100 & $93.3 \pm 1.1 b$ & $88.7 \pm 1.0 \mathrm{~b}$ & $77.0 \pm 1.1 \mathrm{~d}$ & $57.5 \pm 1.2 c$ & $63.4 \pm 1.2 \mathrm{~b}$ & $73.6 \pm 1.1 \mathrm{~d}$ \\
\hline & $\mathrm{C} 75$ & $93.3 \pm 1.1 \mathrm{~b}$ & $87.8 \pm 1.1 \mathrm{~b}$ & $79.7 \pm 1.1 \mathrm{c}$ & $65.4 \pm 1.3 c$ & $112.2 \pm 1.4 \mathrm{ab}$ & $94.4 \pm 1.0 \mathrm{~b}$ \\
\hline & $\mathrm{C} 50$ & $100.0 \pm 1.0 \mathrm{a}$ & $98.0 \pm 1.0 \mathrm{a}$ & $86.2 \pm 1.2 \mathrm{~b}$ & $94.2 \pm 1.2 \mathrm{ab}$ & $138.4 \pm 1.7 \mathrm{a}$ & $99.3 \pm 1.0 \mathrm{a}$ \\
\hline & $\mathrm{C} 25$ & $100.0 \pm 1.0 \mathrm{a}$ & $102.5 \pm 1.1 \mathrm{a}$ & $93.0 \pm 1.1 \mathrm{a}$ & $110.0 \pm 1.2 \mathrm{a}$ & $163.4 \pm 1.5 \mathrm{a}$ & $90.3 \pm 1.0 \mathrm{c}$ \\
\hline \multirow{4}{*}{ Rocket } & C100 & $66.7 \pm 1.2 \mathrm{a}$ & $103.1 \pm 1.1 \mathrm{a}$ & $93.9 \pm 1.2 \mathrm{a}$ & $59.3 \pm 1.2 \mathrm{a}$ & $83.6 \pm 1.1 \mathrm{~b}$ & $185.6 \pm 1.0 \mathrm{a}$ \\
\hline & C75 & $80.0 \pm 1.3 \mathrm{a}$ & $89.9 \pm 1.1 \mathrm{a}$ & $83.4 \pm 1.1 \mathrm{a}$ & $51.6 \pm 1.9 \mathrm{a}$ & $73.4 \pm 2.5 b$ & $117.2 \pm 1.6 b$ \\
\hline & C50 & $93.3 \pm 1.1 \mathrm{a}$ & $97.5 \pm 1.2 \mathrm{a}$ & $92.2 \pm 1.1 \mathrm{a}$ & $66.1 \pm 1.6 \mathrm{a}$ & $103.4 \pm 1.1 \mathrm{a}$ & $114.3 \pm 1.0 \mathrm{~b}$ \\
\hline & $\mathrm{C} 25$ & $86.7 \pm 1.1 \mathrm{a}$ & $96.5 \pm 1.1 \mathrm{a}$ & $89.2 \pm 1.0 \mathrm{a}$ & $62.1 \pm 1.2 \mathrm{a}$ & $102.4 \pm 1.1 \mathrm{a}$ & $111.8 \pm 1.5 b$ \\
\hline \multirow{4}{*}{ Chard } & C100 & $60.0 \pm 1.3 b$ & $95.9 \pm 1.4 b$ & $99.8 \pm 1.1 \mathrm{~b}$ & $115.4 \pm 2.5 \mathrm{~b}$ & $76.3 \pm 4.5 b$ & $134.8 \pm 1.2 \mathrm{a}$ \\
\hline & $\mathrm{C} 75$ & $60.0 \pm 1.4 \mathrm{~b}$ & $114.8 \pm 1.2 \mathrm{a}$ & $107.5 \pm 1.2 \mathrm{~b}$ & $95.2 \pm 2.4 \mathrm{~b}$ & $77.9 \pm 2.5 \mathrm{~b}$ & $132.0 \pm 1.0 \mathrm{a}$ \\
\hline & $\mathrm{C} 50$ & $80.0 \pm 2.3 \mathrm{~b}$ & $109.2 \pm 1.8 \mathrm{ab}$ & $102.5 \pm 1.1 \mathrm{~b}$ & $106.3 \pm 6.4 \mathrm{~b}$ & $82.2 \pm 1.5 \mathrm{~b}$ & $124.9 \pm 1.6 \mathrm{a}$ \\
\hline & $\mathrm{C} 25$ & $100.0 \pm 1.0 \mathrm{a}$ & $122.5 \pm 1.1 \mathrm{a}$ & $124.0 \pm 1.0 \mathrm{a}$ & $181.6 \pm 1.2 \mathrm{a}$ & $206.0 \pm 1.8 \mathrm{a}$ & $128.4 \pm 1.2 \mathrm{a}$ \\
\hline \multirow{4}{*}{ Sorrel } & C100 & $100.0 \pm 1.3 \mathrm{~b}$ & $88.8 \pm 1.5 b$ & $91.1 \pm 1.1 \mathrm{c}$ & $51.8 \pm 1.7 \mathrm{~b}$ & $52.3 \pm 1.9 b$ & $55.9 \pm 1.0 \mathrm{~d}$ \\
\hline & $\mathrm{C} 75$ & $108.3 \pm 1.1 b$ & $96.6 \pm 1.1 \mathrm{ab}$ & $106.2 \pm 1.1 \mathrm{~b}$ & $81.4 \pm 1.2 \mathrm{ab}$ & $85.4 \pm 1.2 \mathrm{ab}$ & $77.3 \pm 1.0 \mathrm{c}$ \\
\hline & C50 & $116.7 \pm 1.1 \mathrm{a}$ & $97.2 \pm 1.2 \mathrm{ab}$ & $119.2 \pm 1.0 \mathrm{a}$ & $100.4 \pm 1.1 \mathrm{a}$ & $104.4 \pm 1.3 \mathrm{a}$ & $92.3 \pm 1.3 \mathrm{a}$ \\
\hline & $\mathrm{C} 25$ & $125.0 \pm 1.0 \mathrm{a}$ & $112.3 \pm 1.1 \mathrm{a}$ & $121.5 \pm 1.1 \mathrm{a}$ & $128.3 \pm 1.2 \mathrm{a}$ & $142.3 \pm 1.3 \mathrm{a}$ & $88.3 \pm 1.0 \mathrm{~b}$ \\
\hline \multirow{4}{*}{ Dill } & C100 & $116.0 \pm 1.1 \mathrm{~b}$ & $82.0 \pm 1.1 \mathrm{~b}$ & $80.4 \pm 1.1 c$ & $49.4 \pm 1.3 b$ & $35.6 \pm 1.4 \mathrm{~b}$ & $64.6 \pm 1.1 b$ \\
\hline & C75 & $112.0 \pm 1.3 \mathrm{~b}$ & $82.7 \pm 1.2 \mathrm{~b}$ & $79.4 \pm 1.1 \mathrm{c}$ & $46.7 \pm 1.3 \mathrm{~b}$ & $30.8 \pm 1.4 \mathrm{~b}$ & $64.7 \pm 1.1 \mathrm{~b}$ \\
\hline & C50 & $125.0 \pm 1.0 \mathrm{a}$ & $92.8 \pm 1.1 \mathrm{ab}$ & $93.4 \pm 1.0 \mathrm{~b}$ & $93.7 \pm 1.3 \mathrm{a}$ & $61.4 \pm 1.7 \mathrm{ab}$ & $69.4 \pm 1.0 \mathrm{~b}$ \\
\hline & $\mathrm{C} 25$ & $125.0 \pm 1.0 \mathrm{a}$ & $105.4 \pm 1.0 \mathrm{a}$ & $106.9 \pm 1.1 \mathrm{a}$ & $116.6 \pm 1.3 \mathrm{a}$ & $95.5 \pm 1.2 \mathrm{a}$ & $81.6 \pm 1.0 \mathrm{a}$ \\
\hline
\end{tabular}

Data are reported as percentages relative to the control (\%) of mean values for $n=3 \pm$ SD. Different letters within the same column for each parameter and for each species indicate significant differences among the growing media, according to factorial ANOVA combined with Tukey post-hoc test at $p=0.05$.

The short cultivation period was probably also a reason for the low influence of the compost addition on the SPAD index. In fact, this parameter only showed significantly higher values than the control for sorrel and radish at the lowest dose (C25), with the latter having values that were always higher than the control at all considered doses (Figure 2). 


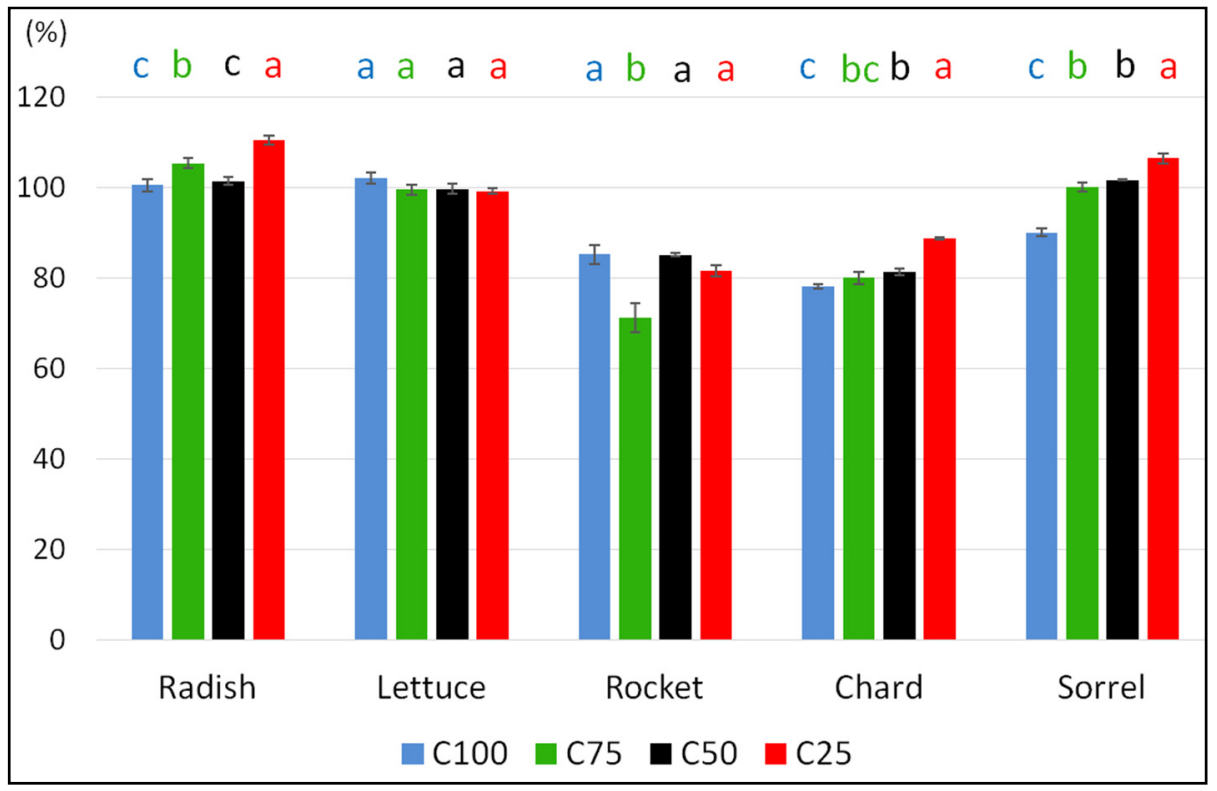

Figure 2. SPAD index measured at the end of the pot trial, in relation to the control (\%) at the different doses of compost added to the growth media. Mean values are expressed as percentages relative to the control $(n=3)$. Bars represent SD of the means. Different letters indicate significant differences $(p=0.05)$ among the growing media, according to factorial ANOVA combined with Tukey post-hoc test.

The correlations among the growth parameters (Table 4) highlighted significant positive relationships between the dry weight of the aboveground biomass and the root dry weight, the seedling height and the number of true leaves.

Table 4. Pearson's correlation between the growth parameters for the studied species at the different doses of the tested compost.

\begin{tabular}{cccccc}
\hline & $\mathbf{H}^{\mathbf{1}}$ & $\mathbf{L N}^{2}$ & $\mathbf{S D W}^{3}$ & RDW $^{\mathbf{4}}$ & MRL $^{5}$ \\
\hline $\mathbf{H}^{1}$ & & $0.68^{* *}$ & $0.73^{* *}$ & $0.51^{* *}$ & $0.67^{* *}$ \\
$\mathbf{L N}^{2}$ & & $0.74^{* *}$ & $0.56^{* *}$ & $0.49^{* *}$ \\
$\mathbf{S D W}^{3}$ & & & $0.77^{* *}$ & 0.34 \\
RDW $^{4}$ & & & & 0.38 \\
\hline
\end{tabular}

${ }^{1} \mathrm{H}=$ Height; ${ }^{2} \mathrm{LN}=$ Leaves number; ${ }^{3} \mathrm{SDW}=$ Shoot dry weight; ${ }^{4} \mathrm{RDW}=$ Root dry weight; ${ }^{5} \mathrm{MRL}=$ Main root length. ** indicate significance at $p=0.01$ for growth parameters mean values $(\mathrm{n}=3)$.

Furthermore, the number of true leaves was correlated with the root dry weight, the main root length and the seedling height, with the latter two also positively correlated with each other. These results confirmed the close relationship between the biomass of the root system and the growth parameters of the aerial part. In fact, the effects of green compost addition to the growth substrate at the lowest doses $(\mathrm{C} 50-\mathrm{C} 25)$ resulted in a general increase for these parameters compared to the control for radish, chard and sorrel. For lettuce, the positive effects were limited to the root system at lower doses, and this may be related to the higher sensitivity of this species to high electrical conductivity [33]. In addition, the general positive effect on the roots could be suitable at nursery level to prepare seedlings for transplantation with well-developed root systems, able to overcome transplant shock more quickly [34].

\section{Conclusions}

The results of our study, conducted on species utilized for ready-to-eat salads, suggest that there is an opportunity to use on-farm compost derived from the fourth range sector 
in the replacement of traditional growing substrate, as long as the right dose is adopted. In fact, the study showed that compost is able to promote the growth of the roots and increase the dry weight of both shoots and roots as consequence of the availability of nutrients.

On the other hand, the effects of compost on plant growth were demonstrated to be species-specific and different depending on dose used.

In general, our study confirmed the statement that the greatest plant growth responses occur at a relatively low proportion of compost in the medium mixture, between C50 and C25, corresponding to $3.5 \mathrm{~g}$ and $1.75 \mathrm{~g}$ per $100 \mathrm{~g}$ of soil, respectively. In particular, the effects of adding compost to the growth substrate at these doses resulted in a good germination response for sorrel and dill and in an increase in the values of the biomass parameters (shoot and root dry weight, seedling height, the number of true leaves), for radish, chard and sorrel, as compared to the control. For lettuce, the positive effects were mainly limited to the root system at the lowest dose, while for rocket, they were limited to root elongation at the highest dose (C100).

The reported results contribute to an expansion of knowledge on the use of compost on species grown for ready-to-eat salads, belonging to the fourth range sector, most of which have, to the best of our knowledge, never been studied before. At the same time, the results also highlight the opportunity to recover on-farm green compost as a partial growth substrate for sustainable crop systems for this kind of cultivation.

In conclusion, the experimentation confirmed that the effects of compost on plant growth must be considered species-specific and also that, although the compost effects are difficult to generalize, the drawbacks associated with the content of salt are partially or totally solvable by properly modulating the applied dose.

Author Contributions: Conceptualization, A.V. and E.D.F.; methodology, A.V. and E.D.F.; validation, A.V. and E.D.F.; formal analysis, E.D.F. and A.V.; investigation, A.V.; resources, E.D.F., G.C. and D.R.; writing — original draft preparation, A.V.; writing—review and editing, A.V., E.D.F. and D.R.; supervision, E.D.F.; project administration, E.D.F. and G.C.; funding acquisition, E.D.F., G.C. and D.R. All authors have read and agreed to the published version of the manuscript.

Funding: This research received no external funding.

Institutional Review Board Statement: Not applicable.

Informed Consent Statement: Not applicable.

Data Availability Statement: The data presented in this study are available on request from the corresponding author.

Conflicts of Interest: The authors declare no conflict of interest.

\section{References}

1. Van der Wurff, A.W.G.; Fuchs, J.G.; Raviv, M.; Termorshuizen, A.J. Handbook for Composting and Compost Use in Organic Horticulture; BioGreenhouse COST Action FA 1105; BioGreenhouse: Wageningen, The Netherlands, 2016. [CrossRef]

2. Chew, K.W.; Chia, S.R.; Yen, H.W.; Nomanbhay, S.; Ho, Y.C.; Show, P.L. Transformation of Biomass Waste into Sustainable Organic Fertilizers. Sustainability 2019, 11, 2266. [CrossRef]

3. Ronga, D.; Villecco, D.; Zaccardelli, M. Effects of compost and defatted oilseed meals as sustainable organic fertilisers on cardoon (Cynara cardunculus L.) production in the Mediterranean basin. J. Hortic. Sci. Biotechnol. 2019, 94, 664-675. [CrossRef]

4. Zaccardelli, M.; Pane, C.; Di Mola, I.; Ronga, D.; Mori, M. Municipal organic waste compost replaces mineral fertilization in the horticultural cropping systems, reducing the pollution risk. Ital. J. Agron. 2021, 16. [CrossRef]

5. Cooperband, L. The Art and Science of Composting-A Resource for Farmers and Compost Producers; University of Wisconsin-Madison, Center for Integrated Agricultural Systems: Madison, WI, USA, 2002; 14p.

6. Scotti, R.; Pane, C.; Spaccini, R.; Palese, A.M.; Piccolo, A.; Celano, G.; Zaccardelli, M. On-farm compost: A useful tool to improve soil quality under intensive farming systems. Appl. Soil. Ecol. 2016, 107, 13-23. [CrossRef]

7. Xu, L.; Geelen, D. Developing Biostimulants From Agro-Food and Industrial By-Products. Front. Plant Sci. $2018,9,1-13$. [CrossRef] [PubMed]

8. Ronga, D.; Vitti, A.; Zaccardelli, M.; Pane, C.; Caradonia, F.; Cardarelli, M.; Colla, G.; Rouphael, Y. Root Zone Management for Improving Seedling Quality of Organically Produced Horticultural Crops. Agronomy 2021, 11, 630. [CrossRef] 
9. Islam, M.T.; Faruq, A.N. Effect of selected soil amendments on seed germination, seedling growth and control of dampig-off of chilli seedlings. J. Sher-e-Bangla Agric. Univ. 2008, 2, 12-16.

10. Lazcano, C.; Arnold, J.; Tato, A.; Zaller, J.G.; Dominguez, J. Compost and vermicompost as nursery pot components: Effects on tomato plant growth and morphology. Span. J. Agric. Res. 2009, 7, 944-951. [CrossRef]

11. Ronga, D.; Pane, C.; Zaccardelli, M.; Pecchioni, N. Use of spent coffee ground compost in peat-based growing media for the production of basil and tomato potting plants. Commun. Soil Sci. Plant Anal. 2016, 47, 356-368. [CrossRef]

12. Gavilanes-Terán, I.; Jara-Samaniego, J.; Idrovo-Novillo, J.; Bustamante, M.A.; Pérez-Murcia, M.D.; Pérez-Espinosa, A.; López, M.; Paredes, C. Agroindustrial compost as a peat alternative in the horticultural industry of Ecuador. J. Environ. Manag. 2017, 186, 79-87. [CrossRef]

13. Herring, P.L.; Noah, A.C.; Kraus, H.T. Swine Lagoon Compost as Transplant Substrate for Basil, Chives, and Dill. HortTech 2018, 28, 337-343. [CrossRef]

14. Ronga, D.; Francia, E.; Allesina, G.; Pedrazzi, S.; Zaccardelli, M.; Pane, C.; Tava, A.; Bignami, C. Valorization of vineyard by-products to obtain composted digestate and biochar suitable for nursery grapevine (Vitis vinifera L.) production. Agronomy 2019, 9, 420. [CrossRef]

15. Pergola, M.; Persiani, A.; Palese, A.M.; Di Meo, V.; Pastore, V.; D'Adamo, C.; Celano, G. Composting: The way for a sustainable agriculture. Appl. Soil Ecol. 2018, 123, 744-750. [CrossRef]

16. Aleandri, M.P.; Chilosi, G.; Muganu, M.; Annamaria Vettraino, A.; Marinari, S.; Paolocci, M.; Luccioli, E.; Vannini, A. On farm production of compost from nursery green residues and its use to reduce peat for the production of olive pot plants. Sci. Hortic. 2015, 193, 301-307. [CrossRef]

17. Nicola, S.; Fontana, E. Fresh-Cut Produce Quality: Implications for a Systems Approach. In Postharvest Handling: A Systems Approach, 3rd ed.; Florkowski, W., Shewfelt, R., Brueckner, B., Prussia, S., Eds.; Academic Press/Elsevier: New York, NY, USA, 2014; pp. 217-273.

18. Luo, Y.; Liang, J.; Zeng, G.; Chen, M.; Mo, D.; Li, G.; Zhang, D. Seed germination test for toxicity evaluation of compost: Its roles, problems and prospects. Waste Manag. 2018, 71, 109-114. [CrossRef] [PubMed]

19. Jayasinghe, G.Y.; Tokashiki, Y.; Arachchi, I.D.L.; Arakaki, M. Sewage sludge sugarcane trash based compost and synthetic aggregates as peat substitutes in containerized media for crop production. J. Hazard. Mater. 2010, 174, 700-706. [CrossRef] [PubMed]

20. Marcelis, L.F.M.; Van Hooijdonk, J. Effect of salinity on growth, water use and nutrient use in radish (Raphanus sativus L.). Plant Soil 1999, 215, 57-64. [CrossRef]

21. Giandon, P.; Bortolami, P. L'interpretazione Delle Analisi del Terreno-Strumento per la Sostenibilità Ambientale, 2nd ed.; Centrooffset s.r.l. for ARPAV: Mestrino, Italy, 2007; pp. 15-16, ISBN 88-7504-115-6.

22. Charles, J.; Sancey, B.; Morin-Crini, N.; Badot, P.M.; Degiorgi, F.; Trunfio, G.; Crini, G. Evaluation of the phytotoxicity of polycontaminated industrial effluents using the lettuce plant (Lactuca sativa) as a bioindicator. Ecotoxicol. Environ. Saf. 2011, 74, 2057-2064. [CrossRef]

23. Cesaro, A.; Belgiorno, V.; Guida, M. Compost from organic solid waste: Quality assessment and European regulations for its sustainable use. Resour. Conserv. Recycl. 2015, 94, 72-79. [CrossRef]

24. Nasri, N.; Saïdi, I.; Kaddour, R.; Lachaâl, M. Effect of Salinity on Germination, Seedling Growth and Acid Phosphatase Activity in Lettuce. Am. J. Plant Sci. 2015, 6, 57-63. [CrossRef]

25. Gong, X.; Li, S.; Sun, X.; Wang, L.; Cai, L.; Zhang, J.; Wei, L. Green waste compost and vermicompost as peat substitutes in growing media for geranium (Pelargonium zonale L.) and calendula (Calendula officinalis L.). Sci. Hortic. 2018, 236, 186-191. [CrossRef]

26. Erhart, E.; Hartl, W. Compost use in organic farming. In Genetic Engineering, Biofertilisation, Soil Quality and Organic Farming. Sustainable Agriculture Reviews; Lichtfouse, E., Ed.; Springer: Dordrecht, The Netherlands, 2010; pp. 311-345. [CrossRef]

27. Getinet, A. A review on impact of compost on soil properties, water use and crop productivity. Agric. Sci. Res. J. 2016, 4, 93-104.

28. Gonzalez, R.F.; Cooperband, L.R. Compost Effects on Soil Physical Properties And Field Nursery Production. Compost. Sci. Util. 2002, 10, 226-237. [CrossRef]

29. Caruso, G.; Parrella, G.; Giorgini, M.; Nicoletti, R. Crop Systems, Quality and Protection of Diplotaxis tenuifolia. Agriculture 2018, 8, 55. [CrossRef]

30. Caruso, G.; Conti, S.; La Rocca, G. Influence of crop cycle and nitrogen fertilizer form on yield and nitrate content in different species of vegetables. Adv. Hortic. Sci. 2011, 25, 81-89.

31. Guo, X.-X.; Liu, H.-T.; Wu, S.-B. Humic substances developed during organic waste composting: Formation mechanisms, structural properties, and agronomic functions. Sci. Total Environ. 2019, 662, 501-510. [CrossRef] [PubMed]

32. Canellas, L.P.; Olivares, F.L.; Aguiar, N.O.; Jones, D.; Nebioso, A.; Mazzei, P.; Piccolo, A. Humic and fulvic acids as biostimulants in horticulture. Sci. Hortic. 2015, 196, 15-27. [CrossRef]

33. Morales-Corts, M.; Gómez-Sánchez, M.; Pérez-Sánchez, R. Evaluation of green/pruning wastes compost and vermicompost, slumgum compost and their mixes as growing media for horticultural production. Sci. Hortic. 2014, 172, 155-160. [CrossRef]

34. Eklind, Y.; Rämert, B.; Wivstad, M. Evaluation of Growing Media Containing Farmyard Manure Compost, Household Waste Compost or Chicken Manure for the Propagation of Lettuce (Lactuca sativa L.) Transplants. Biol. Agric. Hortic. 2001, 19, 157-181. [CrossRef] 